\title{
Hughes confirms its faith in excellence
}

\section{Colin Macilwain}

\section{Over the past decade, the Howard Hughes Medical Institute has seen a steady escalation in the value of both its endowment and its reputation as a source of support for high-quality biomedical research.}

[WASHINGTON] For a fortunate group of America's best life scientists, things will never be the same again after next Monday, 19 May. On that day, this élite will join the staff of the Howard Hughes Medical Institute (HHMI) as part of the philanthropic organization's largest expansion their number comfortably exceeding the 44 investigators added in 1994.

The researchers will be assured of generous support from HHMI for five or seven years and of virtually unfettered freedom to interrogate nature in whichever way they choose.

The emergence of Hughes over the past decade as a major player in the support of biomedical research means that many of the very best researchers are no longer dependent on public funds, a major departure for biomedical research in the United States.

HHMI will spend $\$ 450$ million this year on research, grants and programmes (see graph). In comparison, the publicly funded National Institutes of Health spend $\$ 12.5$ billion. But, according to the Institute for Scientific Information (ISI) in Philadelphia, Howard Hughes investigators have in recent years produced about a quarter of the most cited biomedical research papers.

In the first two months of this year, 12 of the 50 most frequently cited biomedical papers published since 1995 were written by HHMI individuals. "The trend is clearly for the private entities to fund the best work," says David Pendlebury, a senior analyst at ISI. "In a broad sense, this is a privatization."

Monday's announcement will further strengthen HHMI's existing core of 279 investigators, based at 60 medical colleges and research institutes across the United States.

HHMI was founded by Howard Hughes in 1953 as a small charity with large tax advantages. It came into its own in 1985, when the complex unravelling of the eccentric billionaire's estate combined with the sale of the Hughes Aircraft corporation for $\$ 5$ billion to leave the institute with the largest endowment of any research trust in the world.

Pressed by the Inland Revenue Service to spend at least 3.5 per cent of the endowment on medical research everyyear, HHMI quickly embarked on a programme to build and operate laboratories at selected universities and medical schools across the United States.

Under the leadership of Purnell Choppin, a virologist and former administrator at Rockefeller University, New York, who joined HHMI as chief scientific officer in 1985 and became its president two years later, it has since moved steadily towards supporting individual investigators, wherever they work. All the new investigators - who will be listed at www.hhmi.org/whatsnew/ on the Internet on 19 May - will become HHMI employees, and their universities will enter agreements with Hughes to support their work at their existing laboratories.

The winners were chosen in March by the 45 members of HHMI's medical advisory and scientific review boards from 370 nominations received from 200 universities, medical schools and other research institutions.

Max Cowan, chief scientific officer at HHMI, says that he is aware of the risk that this process may merely perpetuate HHMI's existing scientific interests. "You're always biased towards the things you already know," he says. But Cowan promises that the new appointments will ensure that HHMI broadens its interests within each of the five disciplines around which it organizes its work immunology, cell biology, genetics, neuroscience and structural biology.

In structural biology, HHMI will add specialists in electromicroscopy and nuclear magnetic resonance, and in bio-organic chemistry. In neuroscience, where HHMI began with a sharp focus on cellular work, the newcomers will include people working in cognitive neuroscience. There will also be

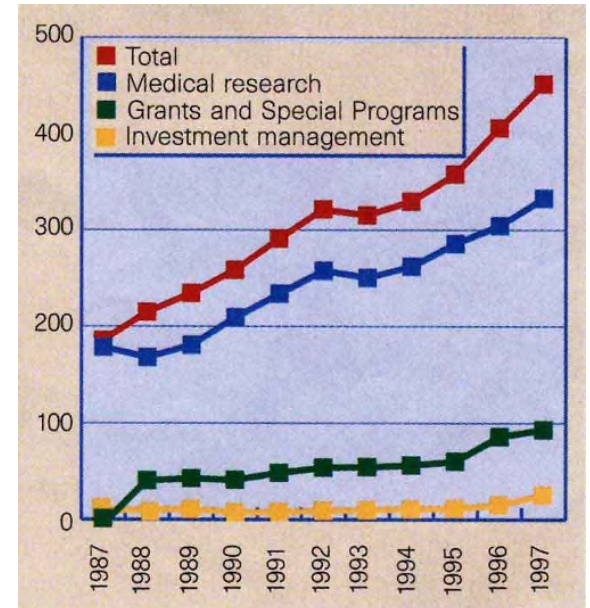

Spending by the Howard Hughes Medical Institute, 1987-97. more researchers with strong clinical interests, Cowan says.

HHMI's charter restricts its interest to biomedical research - which is just as well, in Cowan's view. "One of our strengths is that we haven't tried to become a 'science institute'," he says. "You can think of plenty of philanthropic organizations who have tried to become all things to all people."

Aided by a strong stock market, Hughes' endowment has surged in value. Last year, as HHMI spent \$406 million, its net assets grew by $\$ 446$ million, to $\$ 8.8$ billion. Asked why it does not spend more, Choppin says that the research expenditure - \$304 million in 1996 - is determined by what it considers sustainable "in the very long term".

"We've had the luxury of expanding the endowment because the market has been favourable," says Choppin. HHMI has expanded its grant programmes, which support science education at various levels in the United States, as well as research in eastern Europe, Canada and South America. Unlike the research programme, Choppin says, these can be cut back quickly if the market deteriorates.

Choppin dismisses the suggestion that Hughes, by choosing to fund only a few, wellestablished scientists, discriminates against the young or adventurous. He says HHMI supports $350 \mathrm{PhD}$ students - 100 medical students interested in research, and 700 postdoctoral associates.

According to David Blake, vice-president for research at the American Association of Medical Colleges and former dean of research at Johns Hopkins University in Baltimore, Maryland, many universities have experienced problems integrating HHMI investigators and their publicly funded colleagues.

Blake says Hopkins pioneered arrangements to ensure that facilities were shared and that each group had comparable salaries and benefits. "Some institutions didn't do that, and great animosity developed."

No one doubts the excellence of HHMI's work. But some critics of the government's system for supporting research are using it to highlight what they regard as the shortcomings of the National Institutes of Health. "Hughes is élitist, and so it should be," says Cecil Fox, who runs a private immunology laboratory in Gaithersburg, Maryland. "I can always tell an HHMI investigator - they have a class and a style that is being passed on. Publicly funded science will continue to be mediocre - and it'll continue to get worse."

But political support for publicly funded biomedical research remains strong, and seems unthreatened by the emergence of alternative funding sources such as HHMI. "Both models work," says Tony Fauci, director of the National Institute of Allergy and Infectious Diseases. "There are enough outstanding scientists for them to complement each other, rather than compete." 